\title{
FIRST LARGE EXTENT AND HIGH RESOLUTION CROPLAND AND CROP TYPE MAP OF ARGENTINA
}

\author{
D. de Abelleyra ${ }^{1 *}$, S. Verón ${ }^{1,2,3}$, S. Banchero ${ }^{1}$, M., J. Mosciaro ${ }^{4}$, T. Propato ${ }^{1,2}$, A. Ferraina ${ }^{1,2}$, M.C. Gómez Taffarel, L. Dacunto, A. \\ Franzoni $^{4}$, J.,Volante ${ }^{4}$ \\ ${ }^{1}$ Instituto de Clima y Agua, CIRN, INTA, (1686) Hurlingham, Argentina - (deabelleyra.diego@inta.gob.ar) \\ ${ }^{2}$ CONICET, Argentina \\ ${ }^{3}$ Departamento de Métodos Cuantitativos, FAUBA, Argentina \\ ${ }^{4}$ Estación Experimental Agropecuaria Salta, INTA, Salta, Argentina
}

KEY WORDS: Agricultural Systems, spatial distribution, soybean, maize, wheat, Pampas, Chaco

\begin{abstract}
:
The availability of spatially explicit information about agricultural crops for large regions in Argentina is scarce. In particular, due to temporal dynamics of agricultural production (i.e. changes in planted crops from year to year) and spectral similarities among herbaceous crops it is difficult to generate crop type maps from remote sensing. Large regions with marked climatic variations, like the main agricultural areas of Argentina, represent an additional challenge. Here we generated a map based on supervised classifications using field samples along 14 agricultural zones. Best classification accuracies were obtained by combining seasonal indices (year, summer and winter), with indices that describe the temporal dynamics of vegetation. Accuracy was increased at regions with high and balanced number of samples and with longer growing seasons. The map allows to identify areas with clusters of one, two or three crops and to characterize areas with different spatial distribution between cropland and no cropland areas.
\end{abstract}

\section{INTRODUCTION}

Satellite images and processing capability available nowadays allows the generation of high resolution maps over large regions. Identification of crop types from satellite images is still a challenge since it is necessary to separate covers with high similarities: i.e. herbaceous vegetation in homogeneous stands growing over similar environmental conditions. Available methods vary from empirical decision trees to automatic supervised classification methods. Difficulties depend on the number and similarities/dissimilarities among crop types (planting dates, reflectance properties, etc.), that can be relevant when analysing large areas.

Previous works in Argentina were oriented to map specific crops (soybean (Song et al., 2017); Sugar cane (Benedetti, 2018)), small regions (Badwart et al., 1987; Pressuti et al., 2001; Zelaya et al., 2016), or to describe crop types only over cropland areas (Volante et al., 2006). The generation of crop type maps at national level require the simultaneous acquisition of ground truth information (for training or validation) covering the range of cropping systems along the country, as well as the acquisition and processing of high temporal and spatial resolution satellite images that covers the study region.

\section{MATERIALS AND METHODS}

Supervised classifications (i.e. the utilization of samples for training and validation of classification algorithms) were performed using satellite images to generate crop type maps for the growing season 2018/2019.

\subsection{Study area}

The mapped area covers the main agricultural areas of Argentina (Figure 1). The region was divided in 14 zones, following Buenos Aires Grain Exchange (2019) zonation, which is based on crop production statistics at county level. Original areas were modified intersecting an agroecological zonation (Burkart, 1989) to avoid the inclusion of arid regions in the Western zones. High variability in crop production systems exists along a high temperature and precipitation gradient, with changes in crop species presence and diversity, cropping intensity and planting and harvesting dates. Southern areas have a dominance of winter crops (wheat and barley); In the Center is located the main agricultural area with prevalence of soybean, maize and double crops; in the Northern areas specific crops appears like common bean, cotton, and sugarcane. There are also changes in the proportion of cropland and other land uses, with higher proportion of rangelands in the South, South West and Center West (Entre Ríos province); in the Chaco region there persists natural forest covers and its conversions to pastures.

\subsection{Field sampling}

On road surveys following the JECAM (2018) protocol were performed over all the regions to get information for training and validation of classification algorithms (Figure 1). Surveys were performed twice a year: 1) from October to November to cover winter crops and summer crops fallows; 2) from March to April to cover summer crops and winter crops fallows. Georeferenced points were registered over fields and patches along the roads. Fourteen classes were defined in order to characterize the crop (or crops) that occurred along the growing season (Table 1). For each zone, main crops that represent

* Corresponding author 
together up to $90 \%$ of cropland area, based on county level statistics (MINAGRO, 2019), were considered. Number of samples obtained for each class and zone is described in Table 2. From GPS point samples, polygons of $100 \mathrm{~m}$ radius were generated semi-automatically and assigned to fields or homogeneous patches based on visual interpretation of boundaries using HR images from Google Earth.

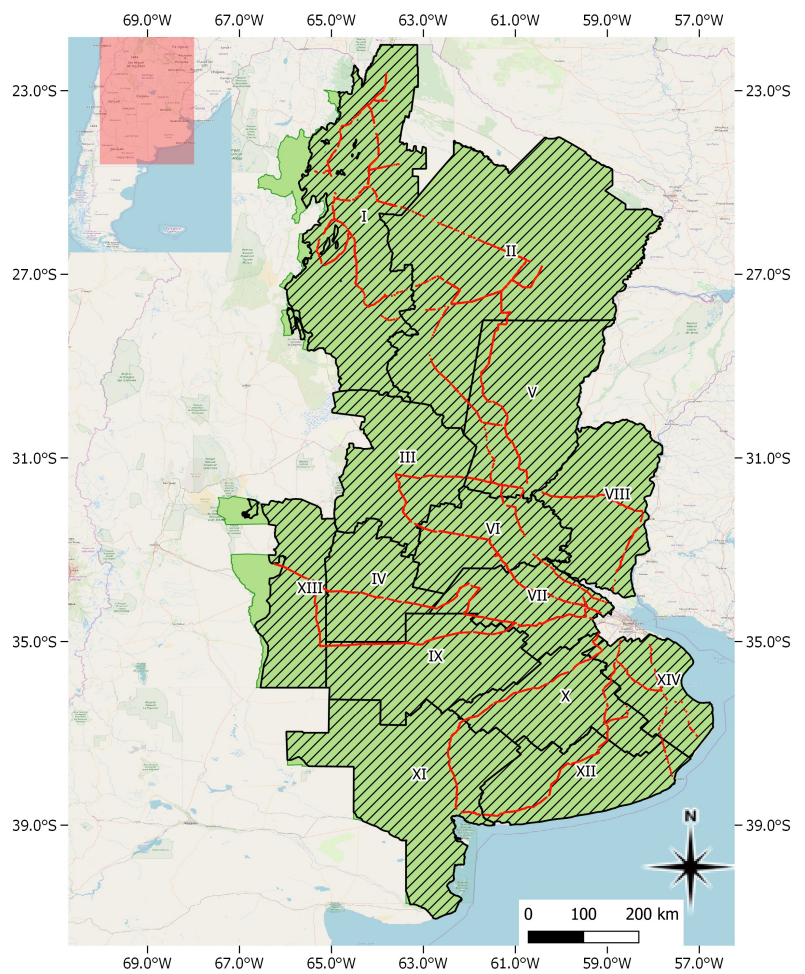

Figure 1. Study region covering Pampa and Chaco, the main agricultural areas of Argentina. Green: Buenos Aires Grain

Exchange zonation; Shaded: Modified zonation; red lines: on road surveys.

\begin{tabular}{|l|c|}
\hline Class ID & Description \\
\hline Maize & Single Crop \\
Soybean & Single Crop \\
WC- Soybean & Winter Crop followed by Soybean \\
WC- Maize & Winter Crop followed by Soybean \\
Peanut & Single Crop \\
Winter Crop & Single Crop \\
Cotton & Single Crop \\
Sunflower & Single Crop \\
Common Bean & Single Crop \\
Sugar Cane & Single Crop \\
Sunflower-SC & Sunflower followed by Summer crop \\
Planted Woody & Planted forests and woody Fruitcrops \\
Rangelands & Land for cattle grazing \\
Natural Woody & Natural woody vegetation \\
\hline
\end{tabular}

Table 1. Classes defined for mapping

\begin{tabular}{|c|c|c|c|c|c|c|c|c|c|c|c|c|c|c|}
\hline Zone & I & II & III & IV & $\mathrm{V}$ & VI & \begin{tabular}{|l|} 
VII \\
\end{tabular} & VIII & IX & $\mathbf{x}$ & $\mathbf{X I}$ & XII & XIII & XIV \\
\hline Maize & 103 & 39 & 75 & 29 & 13 & \begin{tabular}{|l|}
98 \\
\end{tabular} & 138 & \begin{tabular}{|l|}
47 \\
\end{tabular} & 20 & 12 & 14 & 32 & \begin{tabular}{|l|}
41 \\
\end{tabular} & 10 \\
\hline Soybean & 160 & 35 & 65 & 26 & 27 & 103 & 105 & 70 & 28 & 3 & 14 & 36 & 35 & \\
\hline WC- Soybean & 31 & 10 & 59 & 20 & 30 & 83 & 111 & 68 & 27 & 2 & 14 & 21 & & \\
\hline WC- Maize & 53 & 9 & 16 & 5 & 6 & 16 & 8 & 5 & 18 & & & & & \\
\hline Peanut & & & & 9 & & & & & & & & & 8 & \\
\hline Sunflower & & 9 & & & 1 & & & & & 9 & 11 & 14 & & \\
\hline Winter Crop & & & & & & & & & & & 30 & 91 & & \\
\hline Rangelands & 192 & 196 & 30 & 54 & 357 & 41 & 244 & \begin{tabular}{|l|}
254 \\
\end{tabular} & \begin{tabular}{|l|}
50 \\
\end{tabular} & 195 & 176 & 118 & 35 & 135 \\
\hline Natural Woody & 178 & 95 & 5 & 1 & 67 & $3 \mid$ & \begin{tabular}{|l|}
1 \\
\end{tabular} & \begin{tabular}{|l|}
50 \\
\end{tabular} & & & 4 & & 22 & \\
\hline Planted Woody & 82 & & & & & & & 13 & & & & 6 & & \\
\hline Cotton & & 18 & & & & & & & & & & & & \\
\hline Common Bean & 92 & & & & & & & & & & & & & \\
\hline Sugar Cane & 90 & & & & & & & & & & & & & \\
\hline Sunflower-SC & & 29 & & & & & & & & & & & & \\
\hline Total & 981 & 393 & 250 & 144 & 501 & 344 & \begin{tabular}{|c|}
607 \\
\end{tabular} & 507 & 143 & 221 & 263 & 318 & 141 & 145 \\
\hline
\end{tabular}

Table 2. Number of samples generated for each class and zone surveyed during winter and summer season.

\subsection{Satellite images and derived indices}

Landsat 8 image Collections for the study area from June $1^{\text {st }}$, 2018 to May $30^{\text {th }}, 2019$ were considered as input data. We tested 3 feature spaces composed of different type of indices: 1) statistical description indices for fixed periods (SDI); 2) single descriptors of vegetation temporal dynamics (VTD); and 3) parameters of sinusoidal functions (SF). In the first case, 3 fixed periods were considered: annual, winter (from August $1^{\text {st }}$ to November $30^{\text {th }}$ ) and summer (from January $1^{\text {st }}$ to March $30^{\text {th }}$ ) composites. Statistical metrics included: percentiles 5, 25, 50, 75 and 95, and standard deviation. Indices included NDVI, SAVI, SWVI, and spectral unmixing derived indices (Souza and Barreto, 2000). VTD summarized the dynamics of NDVI along the growing season with the following parameters: number of peaks, peak value, peak time, amplitude and growing season duration. Third approach (SF) consisted in the modelling the NDVI temporal dynamics by means of $2^{\text {nd }}$ order harmonic regressions. . Thus input data for the RF classifier consisted on the 5 parameters derived from the harmonic regression fitted at each pixel. Image processing was performed using Google Earth Engine and its catalogue.

\subsection{Classification}

Classification was performed using the Random Forest methodology considering 70 trees. Independent classifications were performed for each of the 14 zones. Samples were split for training $(60 \%)$ and validation $(40 \%)$. In cases were the number of samples of a class identified as relevant in a zone was low, samples of this class were joined with ones from boundary zones from a same latitude gradient. Accuracy for each zone and class was determined, together with the estimation of Kappa index. A spatial filter (Souza and Azevedo, 2017) was applied to avoid the presence of isolated pixels inside a field or patch. Water and water bodies, urban related areas, and wetlands were masked using information from Pekel et al., (2016), IGN (2019) and Volante et al., (2010) respectively. 


\section{RESULTS AND DISCUSSION}

\subsection{Feature space evaluation}

Comparing each feature space separately, VTD showed higher accuracy and Kappa coefficient. Nevertheless, the highest accuracies were obtained combing together SDI and VTD or with the combination of all bands. This result highlights the importance of including temporal description indices to discriminate crops when using satellite images. Following results are based on classifications using the SDV+VTD combination of bands.

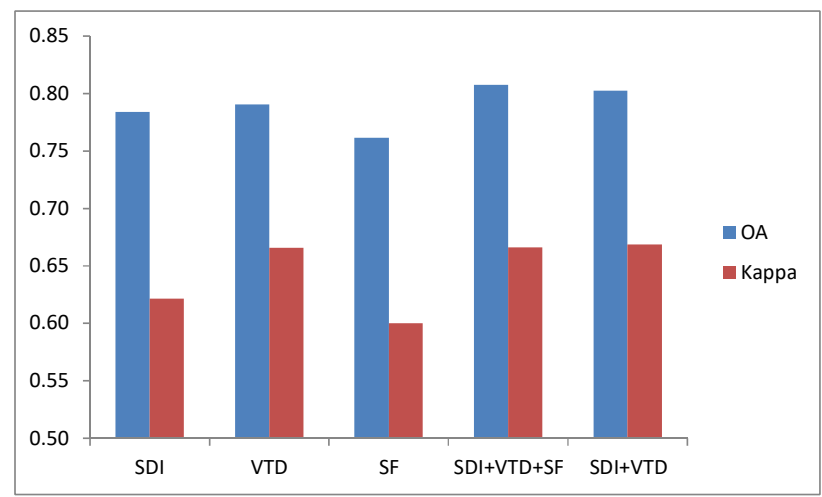

Figure 2. Overall Accuracies (OA) and Kappa coefficient for different feature spaces or combination of them: statistical description indices for fixed periods (SDI); single descriptors of vegetation temporal dynamics (VTD); and parameters of sinusoidal functions (SF).

\subsection{Accuracy of final map}

Overall accuracy and Kappa showed variable results among the different zones (Table 3 ). Accuracy values ranged from 0.63 in zone I to 0.91 in zone XIV, while Kappa ranged from 0.52 in zone $\mathrm{V}$ to 0.85 in zone VII. In general zones with high accuracy (i.e zones VI and VII) showed a high and balanced number of samples among different classes (Tables 2 and 3 ).

\begin{tabular}{|l|c|c|c|}
\hline Zone & OA & Kappa & N classes \\
\hline I & 0.67 & 0.61 & 9 \\
\hline II & 0.77 & 0.69 & 9 \\
\hline III & 0.86 & 0.83 & 6 \\
\hline IV & 0.75 & 0.69 & 7 \\
\hline V & 0.80 & 0.52 & 7 \\
\hline VI & 0.83 & 0.77 & 6 \\
\hline VII & 0.90 & 0.85 & 6 \\
\hline VIII & 0.84 & 0.80 & 7 \\
\hline IX & 0.71 & 0.59 & 6 \\
\hline X & 0.90 & 0.83 & 5 \\
\hline XI & 0.82 & 0.60 & 7 \\
\hline XII & 0.85 & 0.78 & 7 \\
\hline XIII & 0.73 & 0.65 & 5 \\
\hline XIV & 0.91 & 0.75 & 4 \\
\hline
\end{tabular}

Table 3. Overall accuracies (OA), Kappa coefficient and number of classes ( $\mathrm{N}$ classes) obtained for each zone.

User and producer accuracies were high in zones III, VI, VII and VIII for the classes Soybean, Maize, WC- Soybean and Rangelands (Tables 4 and 5). On the other hand, zones I, II and $\mathrm{V}$ showed low user and producer accuracies in several classes, reflecting higher confusion among classes. Several high accuracy zones represents areas located in the Center of the study area with a longer growing season than the rest in relation to better water conditions and moderate temperatures, generating a higher range of variation in planting dates. On the contrary, low accuracy zones located in the North have shorter growing season limited by water in winter and lower differences in planting dates among crops. This variability or homogeneity of growing periods for different crops can explain the observed variability in confusion of classes.

\begin{tabular}{|l|c|c|c|c|c|c|c|c|c|c|c|c|c|c|}
\hline Zone & I & II & III & IV & V & VI & VII & IIII & IX & X & XI & XII & XIII & XIV \\
\hline Maize & 0.6 & 0.8 & 0.8 & 0.9 & 0.9 & 0.9 & 0.9 & 0.8 & 0.5 & 0.9 & - & - & 0.8 & - \\
\hline Soybean & 0.6 & 0.8 & 0.9 & 0.8 & 0.6 & 0.9 & 0.9 & 0.9 & 0.7 & 0.8 & - & - & 0.6 & - \\
\hline WC- Soybean & 0.7 & - & 0.8 & 0.7 & 0.5 & 0.7 & 0.9 & 0.7 & 0.6 & 0.9 & - & - & - & - \\
\hline WC- Maize & 0.8 & - & 0.9 & - & - & 0.9 & - & - & - & & & & & \\
\hline Peanut & & & & - & & & & & & & & & - & \\
\hline Sunflower & & - & & & - & & & & & - & - & - & & \\
\hline Winter Crop & & & & & & & & & & & 1 & 0.9 & & \\
\hline Rangelands & 0.5 & 0.7 & 0.9 & 0.7 & 0.8 & 0.7 & 0.9 & 0.8 & 0.8 & 0.9 & 0.8 & 0.8 & 0.8 & 0.9 \\
\hline Natural Woody & 0.8 & 0.9 & - & - & 1 & - & - & 1 & 1 & & - & & 1 & \\
\hline Planted Woody & 1 & & & & & & & - & & & & - & & \\
\hline Cotton & & - & & & & & & & & & & & & \\
\hline Common Bean & 0.7 & & & & & & & & & & & & & \\
\hline Sugar Cane & 0.9 & & & & & & & & & & & & & \\
\hline Sunflower-SC & & 0.9 & & & & & & & & & & & & \\
\hline
\end{tabular}

Table 4. User accuracies for each zone and class. Only values from classes with more than 20 samples are shown.

\begin{tabular}{|l|c|c|c|c|c|c|c|c|c|c|c|c|c|c|}
\hline Zone & I & II & III & IV & V & VI & VII & VIII & IX & X & XI & XII & XIII & XIV \\
\hline Maize & 0.4 & 0.5 & 0.9 & 0.9 & 0.1 & 0.9 & 0.9 & 0.9 & 0.8 & 0.2 & - & - & 0.7 & - \\
\hline Soybean & 0.8 & 0.5 & 0.8 & 0.9 & 0.5 & 0.8 & 0.9 & 0.8 & 0.5 & 1 & - & - & 0.9 & - \\
\hline WC- Soybean & 0.2 & - & 0.8 & 0.9 & 0.4 & 1 & 0.9 & 0.9 & 0.7 & 0.9 & - & - & & - \\
\hline WC- Maize & 0.5 & - & 0.4 & - & - & 0.2 & - & - & - & & & & & \\
\hline Peanut & & & & - & & & & & & & & & - & \\
\hline Sunflower & & - & & & - & & & & & - & - & - & & \\
\hline Winter Crop & & & & & & & & & & & 0.3 & 0.9 & & \\
\hline Rangelands & 0.8 & 1 & 0.7 & 0.9 & 1 & 0.7 & 0.9 & 1 & 0.8 & 1 & 1 & 1 & 0.8 & 1 \\
\hline Natural Woody & 0.8 & 0.8 & - & - & 0.5 & - & - & 0.8 & 0.7 & & 0.6 & & 0.8 & \\
\hline Planted Woody & 0.6 & & & & & & & 0.8 & & & & 0.2 & & \\
\hline Cotton & & - & & & & & & & & & & & & \\
\hline Common Bean & 0.3 & & & & & & & & & & & & & \\
\hline Sugar Cane & 0.8 & & & & & & & & & & & & & \\
\hline Sunflower-SC & & 0.7 & & & & & & & & & & & & \\
\hline
\end{tabular}

Table 5. Producer accuracies for each zone and class. Only values from classes with more than 20 samples are shown.

\subsection{Map Description}

Figure 3 shows the spatial distribution of crops as well as rangelands and woody vegetation. The map show areas with dominance of one crop, like Maize in zones III and XII, Winter Crops in zone XII, as well as mixed patterns of two crops (Maize and Soybean in South West of zone III and North West of zone IV), or three crops patterns (Soybean, Maize and WCSoybean in Zones VII and VII).

The map also shows differences in spatial distribution of cropland in relation to no cropland classes. Areas mainly dominated by croplands are observed in South West of zone III, and Center of zone VI. Cropland areas fragmented with low proportion of rangelands are observed in several regions: West of zone III, zone IV, North of zone VI and zone VII. Zone VIII show a pattern with no dominance of cropland or no cropland classes with mixed patches of natural woody vegetation. Also it is possible to identify large rangeland dominated areas with a clear limit with cropland dominated areas (Zones X, XI and XII). Northern regions show high proportion of natural woody 
vegetation, surrounded by small (zone I) or large (zone II) cropland or mixed cropland-rangeland areas.

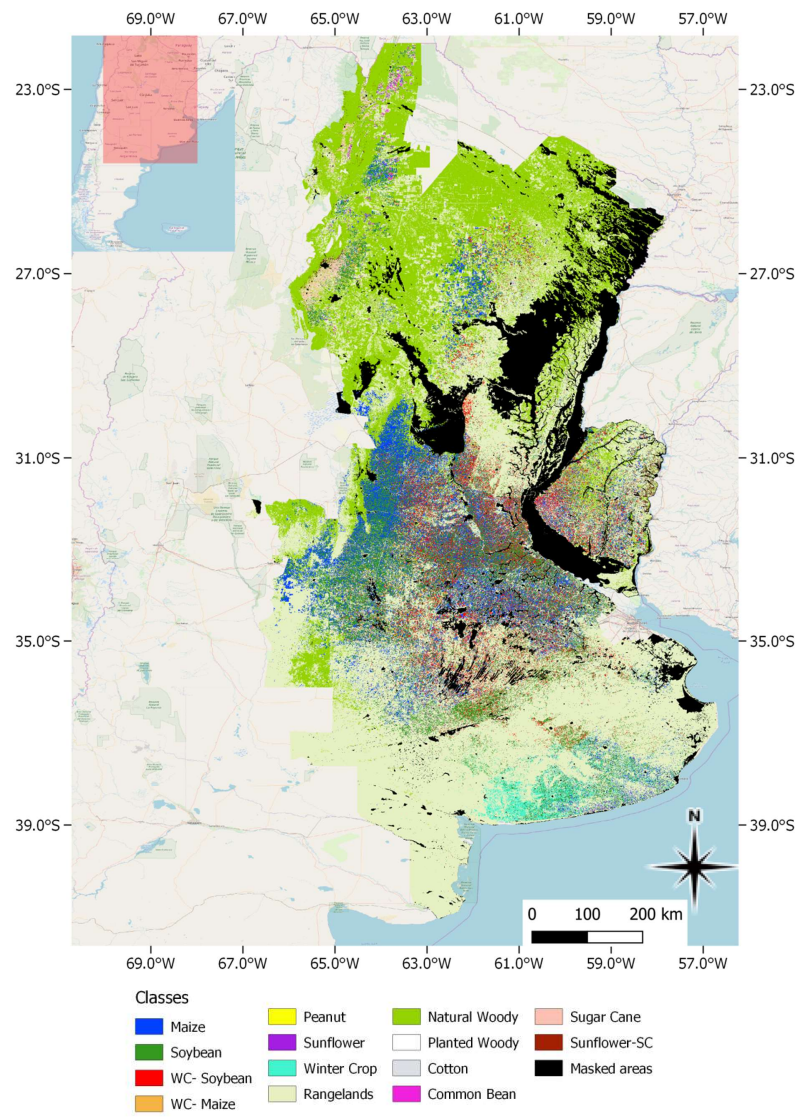

Figure 3. Cropland and crop type map of main agricultural areas of Argentina for the 2018/2019 growing season. Classes are described in Table 2 .

\section{CONCLUSSIONS}

We generated a high resolution extensive cropland and crop type map covering main agricultural areas of Argentina for the growing season 2018/2019 based on field observations. The information provided by this crop type map complements and adds to the county level data, currently considered to describe agricultural related aspects in Argentina. Quantitative information derived from this map is not only suitable for estimation of cropland area, as it can be used to optimize the distribution of transport infrastructure like roads, railways and harbours for specific crops. Spatial distribution analysis can be used to characterize agricultural systems along the country, or to analyse the presence of animals related to described land covers patterns (biodiversity analysis, plague incidence, etc.).

Repetition in time of these maps will allow the characterization of agricultural expansion, changes in agricultural systems, and spatial distribution of crop sequences (i.e crop rotation and monoculture). The map is available at GEOINTA platform (http://geointa.inta.gob.ar).

\section{ACKNOWLEDGEMENTS}

This research was supported by SIGMA Project "Stimulating Innovation for Global Monitoring of Agriculture" (Agreement 22854 - INTA - UNIÓN EUROPEA - Flemish institute for
Technological Research (VITO)) and MapBiomas Project (Agreement 26121 - INTA - The Nature Conservancy).

\section{REFERENCES}

Badhwar, G. D., Gargantini, C. E., Redondo, F. V., 1987. Landsat classification of Argentina summer crops. Remote Sensing of Environment, 21: 111-117.

Benedetti, P.E., 2018. Primer relevamiento del cultivo de caña de azúcar de la República Argentina a partir de imágenes satelitales para la campaña 2018. Informe INTA. URL: https:/inta.gob.ar/sites/default/files/inta_informe_relevamiento _del_cultivo_de_cana_de_azucar_en_argentina_durante_el_201 8_a_partir_de_imagenes_satelitales_1_0.pdf (24 November $2019)$.

Burkart, R., Bárbaro, O., Sanchez, R.O., Gómez, D.A., 1999. Ecorregiones de la Argentina. Administración de Parques Nacionales y Secretaria de Recursos Naturales y Desarrollo Sustentable: Buenos Aires, Argentina.

Buenos Aires Grain Exchange, 2019. Panorama Agrícola Semanal. Departamento de Estimaciones Agrícolas. Newsletter, Bolsa de Cereales de Buenos Aires. http://www.bolsadecereales.com/ver-acerca-del-panoramaagricola-semanal-78\# (27 August 2019).

Congalton, R.G., 1991. A Review of Assessing the Accuracy of Classifications of Remotely Sensed Data. Remote Sensing of Environment, 37: 35-46.

Instituto Geográfico Nacional (IGN), 2019. CAPAS SIG. http://www.ign.gob.ar/NuestrasActividades/InformacionGeoesp acial/CapasSIG (27 August 2019).

Joint Experiment of Crop Assessment and Monitoring (JECAM), 2018. JECAM Guidelines for cropland and crop type definition and field data collection. http://jecam.org/wpcontent/uploads/2018/10/JECAM_Guidelines_for_Field_Data_ Collection_v1_0.pdf (27 August 2019)

MINAGRO, 2018. Estimaciones Agrícolas. Subsecretaría de Agricultura, Dirección Nacional de Estimaciones, Delegaciones y Estudios Económicos. Ministerio de Agroindustria, República Argentina..https://www.agroindustria.gob.ar/datosagroindustrial es (1 December 2018).

Pekel, J.F., Cottam, A., Gorelick, N., Belward, A.S., 2016. High-resolution mapping of global surface water and its longterm changes. Nature, 540: 418-422.

Presutti, M. E., Franklin, S. E., Moskal, L. M., Dickson, E. E., (2001). Supervised Classification of Multisource Satellite Image Spectral and Texture Data for Agricultural Crop Mapping in Buenos Aires Province, Argentina. Canadian Journal of Remote Sensing, 27: 679-684.

Song, X. P., Potapov, P. V., Krylov, A., King, L., Di Bella, C. M., Hudson, A., Hansen, M. C., 2017. National-scale soybean mapping and area estimation in the United States using medium resolution satellite imagery and field survey. Remote Sensing of Environment, 190: 383-395.

Souza, C., Azevedo, T., 2017. Mapbiomas general handbook. MapBiomas: San Pablo, Brasil, p. 1-23. 
Souza Jr, C., Barreto, P., 2000. An alternative approach for detecting and monitoring selectively logged forests in the amazon. International Journal of Remote Sensing, 21: 173-179.

Volante J., Bianchi A., Paoli H., Noé Y., Elena H., Cabral C., 2006. Análisis de la Dinámica del Uso del Suelo Agrícola del Noroeste Argentino Mediante Teledetección y Sistemas de Información Geográfica. Período 2000-2005. INTA, EEA Salta. 53 pp. https://inta.gob.ar/sites/default/files/script-tmpanalisis_de_la_dinamica_del_uso_del_suelo.pdf (20 November 2019).

Volante, J.N., Ayesa, J.A., Bubenik, K., Collado, A.D., Ferreyra, E., Lopez, C., Navarro de Rau, M.F., Pezzola, A., Puente, M., 2010. Cartografía de cobertura del suelo de la República Argentina según el sistema de clasificación LCSSFAO año 2007-08. In: Congreso Argentino de la Ciencia del Suelo. 31 May - 4 june 2010. Rosario, Santa Fé. Argentina.

Zelaya, K., van Vliet, J., Verburg, P. H., 2016. Characterization and analysis of farm system changes in the Mar Chiquita basin, Argentina. Applied Geography, 68: 95-103. 